\title{
Renal angiomyolipoma
}

(iD) Selahattin Çalışkan ${ }^{1}$

(iD) Gülistan Gümrükçü²

(iD)Emrah Özsoy ${ }^{1}$

Damazan Topaktas ${ }^{1}$

(iD) Metin Ishak Öztürk'

1. Haydarpaşa Numune Training and Research Hospital, Department of Urology, Istambul, Turquey 2. Haydarpaşa Numune Training and Research Hospital, Department of Pathology, Istambul, Turquey

\section{SUMMARY}

INTRODUCTION: Angiomyolipoma is one of the most common benign solid renal tumors. We investigated the characteristics of renal angiomyolipomas and the clinical outcomes of patients in the last thirteen years.

METHODS: The medical records of the patients who underwent nephrectomy were reviewed retrospectively from July 2005 to May 2018. The laboratory data, radiology, and pathology reports were recorded. Patients diagnosed with angiomyolipoma were included in the study.

RESULTS: A total of 28 patients were included in the study, eight of them male. The mean age of the patients was 55.89+14.49 years. The patients were treated with open and laparoscopic techniques. Partial nephrectomy was performed in 12 patients(42.85\%). After pathological examination, 23 patients were diagnosed as fat rich, four patients as fat poor, and one as epithelioid angiomyolipoma. There were no recurrences in the follow-up 91.21+48.31 months.

CONCLUSION: Angiomyolipoma is a rare renal tumor in daily urology practice. Clinicians must be aware of its complications and manage patients well.

KEYWORDS: Angiomyolipoma/surgery. Nephrectomy. Kidney Neoplasms.

\section{INTRODUCTION}

Angiomyolipoma is a rare benign tri-phasic soft tissue tumor that contains fat, blood vessels, and smooth muscles in different proportions'. Fujii et al. ${ }^{2}$ reported that the prevalence of angiomyolipoma (AML) was 0.13\% among 17941 patients in Japan. Among benign kidney tumors, AML is the most common type ${ }^{3}$ and accounts for $0.3-.3 \%$ of all renal masses ${ }^{4}$. Approximately $80 \%$ of these tumors occur sporadically. However, the others are associated with tuberous sclerosis complex and predominantly seen in women ${ }^{5}$.

Most of the patients are asymptomatic and diagnosed incidentally because of the widespread use of imaging techniques ${ }^{4}$. The classical triad of symptoms

DATE OF SUBMISSION: 01-Apr-2019

DATE OF ACCEPTANCE: 19-Apr-2019

CORRESPONDING AUTHOR: Selahattin Çalışkan

Tahtakale Mah. Bizimevler 2 Sitesi

B3/48 Ispartakule - Avcılar/İstanbul - Turkey - +90554 7846552

E-mail: dr.selahattincaliskan@gmail.com 
is flank pain, palpable mass, and hematuria ${ }^{6}$. The main complication of AML is retroperitoneal hemorrhage caused by a rupture of the tumor, which can be life-threatening. Patients with Lenk's triad usually also present acute flank pain, abdominal tenderness, and signs of internal bleeding.

In this study, we aimed to investigate the characteristics of AML patients who underwent nephrectomy in our department.

\section{METHODS}

Patients who underwent nephrectomy for renal tumors between July 2005 and May 2018 were reviewed retrospectively using the hospital database. The patients' age, symptoms, laboratory results, need for transfusion in the preoperative and postoperative period, and pathology results were recorded. The follow-up data of both laboratory and ultrasonography-computed tomography results were noted. Patients with missing data and not treated for nephrectomy were excluded.

The pathological examinations were done by a genitourinary pathologist (GG) in the pathology department. Immunohistochemical studies were performed for differential diagnosis. The data were expressed as mean+standard deviation using the MedCalc Statistical Software demo version 17.6 (MedCalc Software bvba, Ostend, Belgium; http :// www.medcalc.org; 2017).

\section{RESULTS}

There were 647 patients in the database. Of these, 28 (4.3\%) were diagnosed with AML and included in the study. The female:male ratio was 2.5 , and the mean age of the patients was $55.89+14.49$ years. The patients' characteristics are shown in Table 1. Most of the patients were asymptomatic and diagnosed by ultrasonography. Blood transfusion was needed in three patients preoperatively, and eight postoperatively. The mean tumor size and follow up was $7.84+4.83 \mathrm{~cm}$ and $91.21+48.31$ months. Partial nephrectomy was performed in 12 patients, and 16 underwent radical nephrectomy. No perioperative and postoperative complications occurred.

On radiological examination, ultrasonography was performed in all patients, computed tomography confirmed the diagnosis in 25 patients, and magnetic resonance techniques were used in three patients (Figure 1). The pathological evaluation classified 23 patients as fat rich AML, four as fat poor, and one as epitheloid (Figure2). Immunohistochemical studies were done in ten patients using desmin, actin, SMA, CD34, CD 117, CD68, HMB-45, and others (Figure-3). None of the patients experienced recurrence and nor died with a mean follow-up period of $91.21+48.31$ months.

\section{DISCUSSION}

Renal angiomyolipoma is one of the most common benign mesenchymal tumors composed of fat cells, smooth muscle cells, and blood vessels ${ }^{7}$. This pathological entity was first defined by Fischer ${ }^{8}$, in 1911, and predominantly affected females rather than males ${ }^{9}$. The prevalence of AML is $0.28 \%$ in males and $0.6 \%$ in females ${ }^{4}$. A proportion of AMLs (20\%) is associated with tuberous sclerosis complex (TSC) ${ }^{9}$. Tuberous sclerosis is an autosomal dominant disorder caused by mutations in the TSC1 and TSC2 genes ${ }^{6}$. Patients with TSC have features of epilepsy, mental retardation, and angiofibroma $^{10}$. Most of the patients(80\%) with TSC develop $\mathrm{AML}^{6}$ generally consisting of multifocal, bilateral, bigger lesions ${ }^{10}$. Sporadic cases of AML usually have small $(<4 \mathrm{~cm})$ and solitary tumors. Most of the sporadic AML patients(80\%) are usually asymptomatic and diagnosed incidentally. The classical triad of symptoms is flank pain, palpable mass, and hematuria. A small proportion of the patients $(10 \%)$ can present retroperitoneal hematoma or hypovolemic shock as the initial symptom. Wunderlich syndrome is a life-threatening

TABLE 1. THE CHARACTERISTICS OF THE PATIENTS

\begin{tabular}{|c|c|}
\hline Number of patients & 28 \\
\hline Male $n, \%$ & $8,28.57$ \\
\hline Female $\mathrm{n}, \%$ & 2071.42 \\
\hline Age (Mean+SD) & $55.89+14.49$ \\
\hline \multicolumn{2}{|l|}{ Symptoms } \\
\hline No $n, \%$ & $24,85.7$ \\
\hline Flank pain $n, \%$ & $2,7.14$ \\
\hline Hematuria n,\% & $2,7.14$ \\
\hline \multicolumn{2}{|l|}{ Blood transfusion } \\
\hline Preoperative n,\% & $3,10.71$ \\
\hline Postoperative n,\% & $8,28.57$ \\
\hline Tumor size (Mean+SD) & $7.84+4.83$ \\
\hline Follow-up & $91.21+48.31$ \\
\hline \multicolumn{2}{|l|}{ Treatment } \\
\hline Open radical nephrectomy & $16,57.14$ \\
\hline Open partial nephrectomy & $11,39.28$ \\
\hline Laparoscopic partial nephrectomy & $1,3.57$ \\
\hline
\end{tabular}


FIGURE 1. MAGNETIC RESONANCE IMAGING OF AML PATIENTS WHO UNDERWENT PARTIAL NEPHRECTOMY

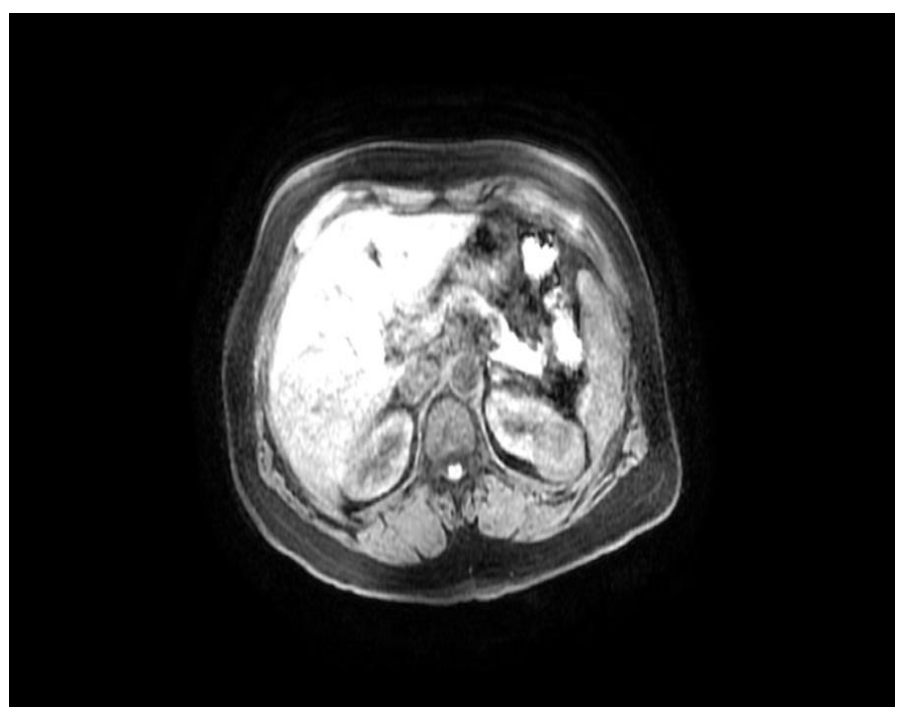

FIGURE 2. FAT-RICH AML INCLUDES FAT TISSUE AND VASCULAR AREA H\&E*100

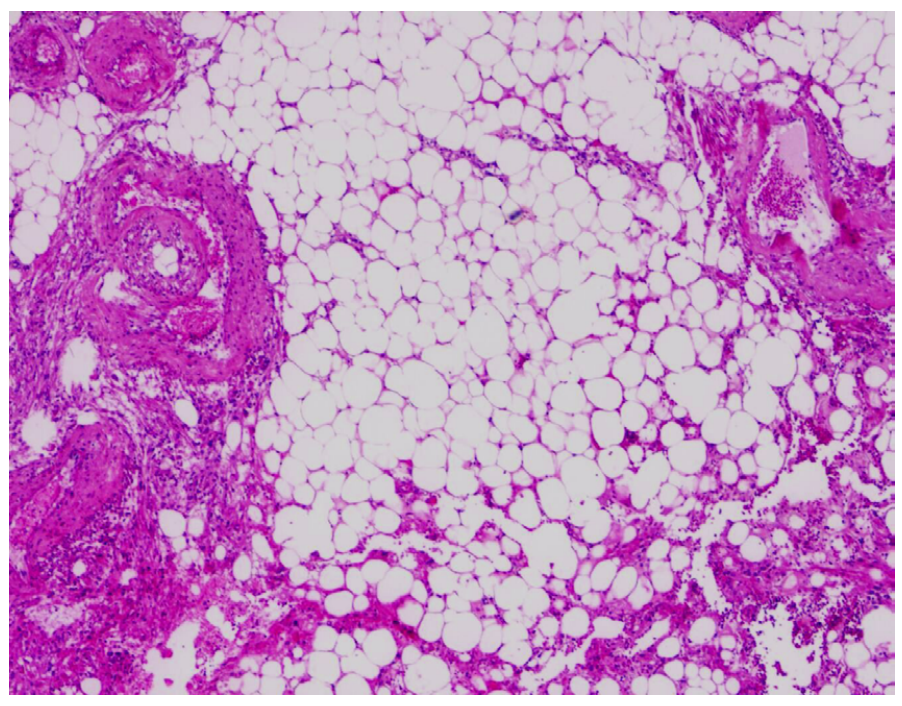

FIGURE 3. EPITHELOID AML WITH POSITIVE STAINING OF HMB- 45 (IMMUNOHISTOCHEMICAL STUDY X 400)

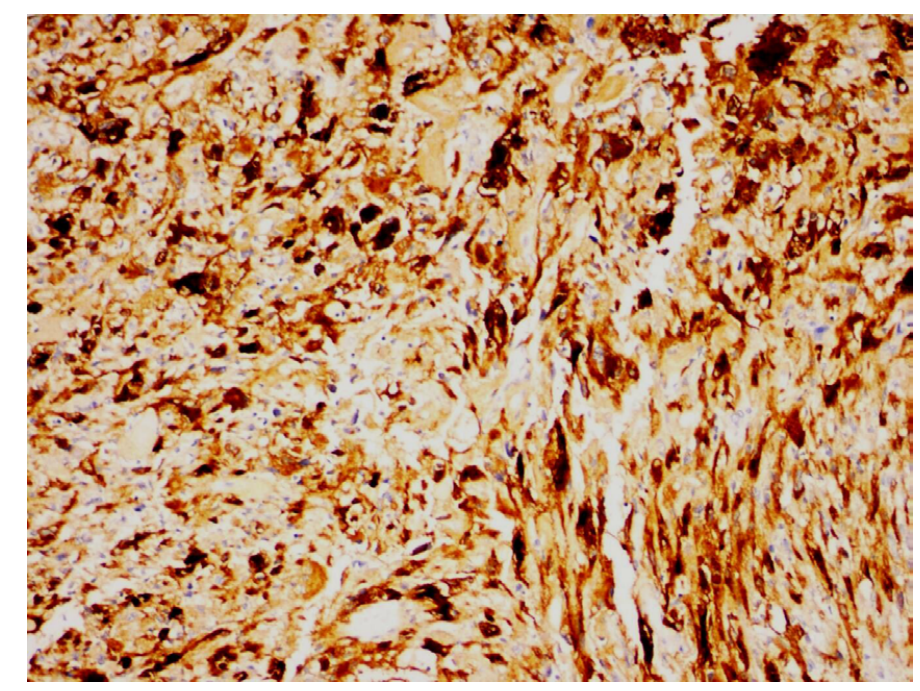

emergency condition characterized by nontraumatic spontaneous hemorrhage in the perinephric space ${ }^{11}$. The patients' symptoms vary and usually include Lenk's triad in addition to acute flank pain, flank mass, and hypovolemic shock. Kim et al. ${ }^{11}$ analyzed 26 patients with Wunderlich syndrome and found $12 \%$ of them were diagnosed with AML. The age of diagnosis varies; patients with TSC are more likely to develop the condition earlier, such as at the third and fourth decades of life. However, sporadic cases present at the fifth and sixth decades 9 . Similarly to what is found in the literature, most of the patients were female, and their mean age was in the sixth decade.

Ultrasonography is not very sensitive for AML, it usually shows a hyperechoic lesion with acoustic shadowing which cannot be differentiated from other kidney tumors ${ }^{6}$. After the diagnosis of AML, ultrasonography may be used in the follow-up period ${ }^{9}$. Computed tomography (CT) with contrast enhancement is the most commonly used radiologic method to diagnose $\mathrm{AML}^{6}$. It has excellent sensitivity, specificity, positive and negative predictive values regarding AML and differentiates it from other lesions. Areas with attenuations less than 10-20 Hounsfield units (HU) are generally considered a diagnostic of macroscopic fat ${ }^{1}$. Some kinds of renal tumors with fat can mimic AML. The other advantages are that it is rapid, cost-effective, and available in most hospitals 9 . Magnetic resonance imaging (MRI) has high sensitivity for detecting fat tissues, so it is useful to differentiate AML from other renal masses ${ }^{6}$. The T1-weighed imaging as hyperintense and T2-weighed as hyposignal on fat-poor AML and epithelioid AML. Israel et al. ${ }^{12}$ reported that 'India link artifact' signal has a high sensitivity (100\%) and specificity (97.9\%) for AML diagnosis. The main disadvantage of MRI is its high cost and being time-consuming when compared to ultrasonography and $\mathrm{CT}^{10}$.

Most asymptomatic patients with AML can be managed by surveillance ${ }^{13}$. The clear diagnosis of AML needs a biopsy, but it is very rarely used because of the tumor rupture and bleeding risks ${ }^{6}$. Although there is no standard protocol for surveillance, physical examination and CT at 6 months, 12 months and annually is recommended ${ }^{10}$. A close follow-up is necessary for high-risk patients, namely women in childbearing age, larger tumor size, and TSC associated $\mathrm{AML}^{10,13}$. Watanabe et al. ${ }^{14}$ reported a case of renal AML growth after ovarian stimulation therapy.

Symptomatic renal AML or big tumor size $>4-6 \mathrm{~cm}$ is widely accepted as an indication of other treatment 
modalities including surgery, embolization, and mammalian target of rapamycin(mTOR) inhibitor therapy ${ }^{4}$. For asymptomatic patients of TSC related AML bigger than $3 \mathrm{~cm}$ size, mTOR inhibitors are the first line prophylactic treatment ${ }^{13}$. These drugs inhibit vascular epithelial proliferation and reduce tumor size, so the risks of tumor rupture and bleeding decrease ${ }^{6}$. Embolization is the first line treatment for bleeding AML and a preventive method for patients with a high risk of bleeding. This procedure is minimally invasive with a high success rate ${ }^{13}$. Sometimes embolization can be performed to facilitate open and laparoscopic partial nephrectomy procedures.

Nephrectomy, partial or total, was the most common treatment for symptomatic cases, emergency hemorrhage, suspicion of malignancy, and prophylaxis in the early years ${ }^{13}$. Partial nephrectomy is a widely accepted modality for its feasibility, efficacy, and satisfaction for renal preservation ${ }^{6}$. These surgical procedures can be done by laparoscopic and robotic approaches with low complication rates ${ }^{13}$. Liu et al. ${ }^{5}$ reported that retroperitoneal laparoscopic partial nephrectomy is a safe, feasible, and effective procedure for large renal AML $(>7 \mathrm{~cm})$. Microwave tumor ablation, radiofrequency, and cryoablation are other possible treatments for small tumors ${ }^{10}$.

Histologically, there are three types of AML: fat-rich (classical), fat-poor, and epithelioid ${ }^{3}$. These tumors usually exhibit expression of smooth muscle actin, actin, HMB-45, Melan-A, S-100, and CD117 ${ }^{15}$. We found that $82.14 \%$ of the patients were classified as fat rich AML.

The small number of patients from one center and the retrospective study design are the main limitations of the study. The lack of other patients who were treated with nonsurgical treatment modalities is the other limitation.

\section{CONCLUSION}

In conclusion, angiomyolipoma is a benign renal tumor. The characteristics of the tumor must be considered in daily practice because of rupture risk. Clinicians should consider that patients are usually asymptomatic and diagnosed incidentally.

\section{Declaration of Conflicting Interests}

The authors declare no conflict of interest.

\section{RESUMO}

OBJETIVO: O angiomiolipoma é um dos tumores renais benignos sólidos mais comuns. Investigamos as características dos angiomiolipomas renais e os desfechos clínicos dos pacientes nos últimos treze anos.

MÉTODOS: Os prontuários dos pacientes, para os quais a nefrectomia foi realizada, foram revisados retrospectivamente de 2008 a 2018. Os dados laboratoriais, relatórios de radiologia e patologia foram registrados. Os pacientes diagnosticados como angiomiolipoma foram incluídos no estudo.

RESULTADOS: Vinte e oito pacientes foram incluídos no estudo, oito deles do sexo masculino. A média de idade dos pacientes foi de 55,89 + 14,49 anos. Os pacientes foram tratados com técnicas abertas e laparoscópicas. Nefrectomia parcial foi realizada em 12 pacientes (42,85\%). Depois de exame patológico, 23 pacientes foram diagnosticados como ricos em gordura, quatro pacientes como gordurosos e um paciente como angiomiolipoma epitelioide. Nenhum paciente teve recorrências no seguimento.

CONCLUSÕES: O angiomiolipoma é um tumor renal raro na prática urológica diária. Os médicos devem estar cientes das complicações e gerenciar bem os pacientes.

PALAVRAS-CHAVE: Angiomiolipoma/cirurgia. Nefrectomia. Neoplasias renais.

\section{REFERENCES}

1. Sharma G, Jain A, Sharma P, Sharma S, Rathi V, Garg PK. Giant exophytic renal angiomyolipoma masquerading as a retroperitoneal liposarcoma: a case report and review of literature.World J Clin Oncol. 2018;9(7):162-6.

2. Fujii $Y$, Ajima J, Oka K, Tosaka A, Takehara $Y$. Benign renal tumors detected among healthy adults by abdominal ultrasonography. Eur Urol. 1995;27(2):124-7.

3. Sultan G, Masood B, Qureshi H, Mubarak M. Angiomyolipoma of the scrotum: report of a rarely seen case and review of the literature. Turk | Urol. 2017;43(2):223-6.
4. Arslan B, Gürkan O, Çetin B, Arslan ÖA, Göv T, Yazıcı G, et al. Evaluation of $\mathrm{ABO}$ blood groups and blood-based biomarkers as a predictor of growth kinetics of renal angiomyolipoma. Int Urol Nephrol. 2018;50(12):2131-7.

5. Liu X, Ma X, Liu Q, Huang Q, Li X, Wang B, et al. Retroperitoneal laparoscopic nephron sparing surgery for large renal angiomyolipoma: our technique and experience. A case series of 41 patients. Int | Surg. 2018;54(Pt A):216-21.

6. Wang C, Li X, Peng L, Gou X, Fan I. An update on recent developments in rupture of renal angiomyolipoma. Medicine (Baltimore). 2018;97(16):e0497. 
7. Lee W, Choi SY, Lee C, Yoo S, You D, leong IG, et al. Does epithelioid angiomyolipoma have poorer prognosis, compared with classic angiomyolipoma? Investig Clin Urol. 2018;59(6):357-62.

8. Fischer W. Die nierentumoren bei der tuberosen hirnsklerose. Zeigl Beitr Pathol Anat Allg Pathol. 1911;50:235.

9. Flum AS, Hamoui N, Said MA, Yang XI, Casalino DD, McGuire BB, et al. Update on the diagnosis and management of renal angiomyolipoma. J Urol. 2016;195(4 Pt 1):834-46.

10. Wang SF, Lo WO. Benign neoplasm of kidney: angiomyolipoma. J Med Ultrasound. 2018;26(3):119-22.

11. Kim JW, Kim JY, Ahn ST, Park TY, Oh MM, Moon DG, et al. Spontaneous perirenal hemorrhage (Wunderlich syndrome): an analysis of 28 cases. Am
J Emerg Med. 2019;37(1):45-7.

12. Israel GM, Hindman N, Hecht E, Krinsky G. The use of opposed-phase chemical shift MRI in the diagnosis of renal angiomyolipomas. AJR Am J Roentgenol. 2005;184(6):1868-72.

13. Seyam RM, Alkhudair WK, Kattan SA, Alotaibi MF, Alzahrani HM, Altaweel WM. The risks of renal angiomyolipoma: reviewing the evidence. I Kidney Cancer VHL. 2017;4(4):13-25.

14. Watanabe EH, Neves PD, Balbo BE, Sampaio CA, Onuchic LF. Giant renal angiomyolipoma following ovarian stimulation therapy. Urology. 2018;112:e3-e4

15. Wang Z, Gong Q, Fan Q. Expression of E-cadherin in angiomyolipoma. Hum Pathol. 2012;43(12):2348-53. 